悪性髄膜腫の臨床的検討と治療方針

一手術的摘出度, 再発, 放射線治療, performance status に関する検討から一

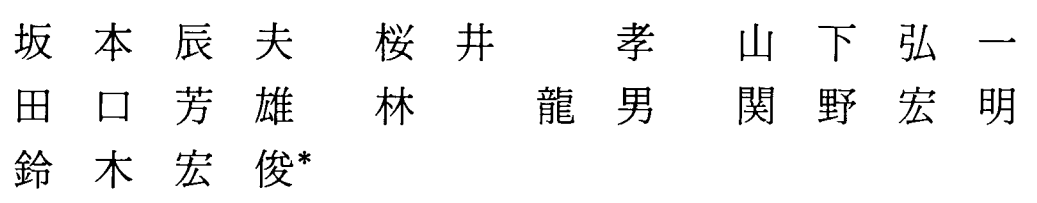

\title{
Clinical Analysis and Management of Malignant Meningiomas : In Connection with Operation, Recurrence, Radiation Therapy and Performance Status \\ by
}

Tatsuo Sakamoto, M.D., Takashi Sakurai, M.D., Koichi Yamashita, M.D., Yoshio Taguchi, M.D., Tatsuo Hayashi, M.D., Hiroaki Sekino, M.D., and Hirotoshi Suzuki, M.D.* from

Division of Neurosurgery, Department of Second Surgery and *Radiology, St. Marianna University School of Medicine

In retrospective review of our malignant meningioma patients, we discussed about clinical analysis and treatment methods. Among 124 cases of surgically treated meningiomas, 11 cases were of malignant meningiomas, which includes 5 cases of atypical meningiomas, 4 cases of anaplastic meningiomas and 2 cases of papillary meningiomas.

Duration of median follow-up was 73 months. The malignant meningiomas patients presented in more than 60 years of age and had poor outcome. Three of surgical treatment with Simpson's grade I had no recurrence. But the other 8 patients, with Simpson's grade II to IV surgical removal had recurrence (sizable regrowth of tumor) and the time elapsed to recurrence from surgical treatment had no statistically significant difference. Conventional radiotherapy was given to 8 cases postoperatively, but could not prevent the enlargement of such tumors. It was known that recurrence of tumor was unavoidable if the tumor could not be removed with Simpson's grade I . However, when the tumor, surgically treated with Simpson's grade II to IV, enlarged following the treatment, if removal of the tumor was performed as soon as possible, performance status of the patient sustained in good condition. The cause of death was not cerebral herniation but gradual deterioration of general condition caused by radiation necrosis following conventional radiotherapy, radical surgical treatment and deterioration of performance status by enlargement of the recurred tumor.

We would like to propose as follows:

1. Surgery should be performed with Simpson's grade I, if possible.

2. Tumor progression must be found out by neuro-imaging study in symptom free period.

3. Cyto-reduction surgery should be performed to preserve the performance status.

4. Stereotaxic radiosurgery may be a suitable choice as a radiation therapy, instead of conventional radiotherapy.

(Received December 14, 1992 ; accepted March 21, 1993)

Key words : malignant meningioma, recurrence, operation, radiation therapy, performance status

Jpn J Neurosurg (Tokyo) $2: 295-301,1993$

聖マリアンナ医科大学第 2 外科脳神経外科診療科〔連絡先：坂本辰夫, テ 216 川崎市宮前区菅生 2-16-1〕

Address reprint requests to: Tatuso Sakamoto, M.D., Division of Neurosurgery, Department of Second Surgery, St. Marianna

University School of Medicine, Sugao 2-16-1, Miyamae-ku, Kawasaki-shi, 216 Kanagawa, Japan

*同放射線科 


\section{緒 言}

悪性髄膜腫にはいまだに明確な治療指針が示されてい るとはいいがたく，日常臨床上いつもわれわれを悩ませ る疾患である。そこでわれわれの施設の過去 17 年間の経 験例を解析し，手術方法，放射線治療と再発，予後との 関係について検討を加えたうえで，治療方針についても 言及したい。

\section{対象および方法}

対象は 1975 年 10 月〜1992 年 9 月までに当院に入院 し腫瘍摘出術を施行した 124 例の随膜腫症例のうち，改 定 WHO 国際脳腫湯組織分類 ${ }^{5}$ に従って WHO grade II とIIIに相当する atypical meningioma, anaplastic meningioma（狭義の malignant meningioma), papillary meningioma と組織診断された 11 例である。疫学 的事項, 再発, 手術的腫場摘出度, 放射線治療, performance status の各事項と予後の関係について retrospective に解析を行った.

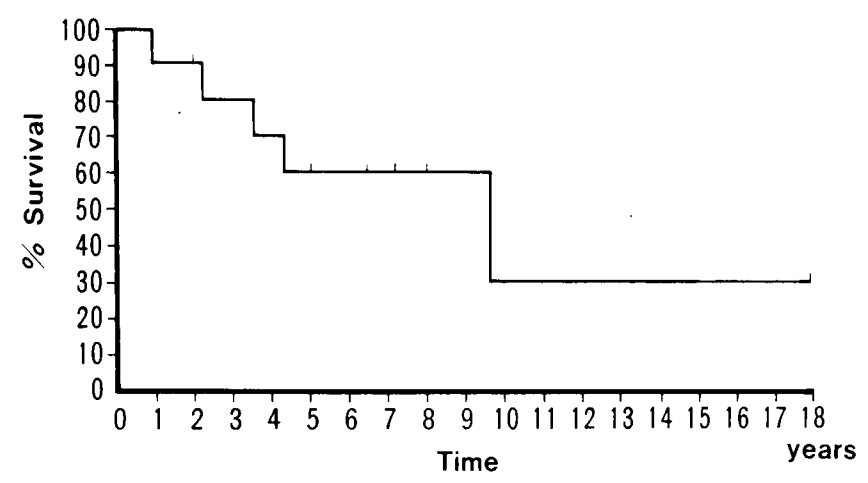

Fig. 1 Survival curve of malignant meningiomas

\section{結 果}

\section{1 症例全体の疫学}

悪性髄膜腫 11 例は全髄膜腫 124 例の $8.9 \%$ を占め, 年 齢は 18〜 77 歳, 平均 53 歳で, 男 6 例, 女 5 例, 男女比 は 1.2：1であった。対象 11 例の平均追跡期間は 73 力 月であった。組織診断は，atypical meningioma 5 例， anaplastic meningioma 4 例, papillary meningioma 2 例であったが，初回腫瘍摘出時の病理診断が再発時に悪 性転化したものが 3 例含まれている(Table 1). KaplanMeier 法による 11 例の生存曲線では，生存期間中央值 は 9 年 7 カ月にあった (Fig. 1)。また症例数は少ないが, 各組織型 3 群間の転帰に logrank 検定で有意差は認め られなかった。

\section{2] 再 発}

初回手術後再発を認めないのは症例 $7,9 ， 10$ で，う

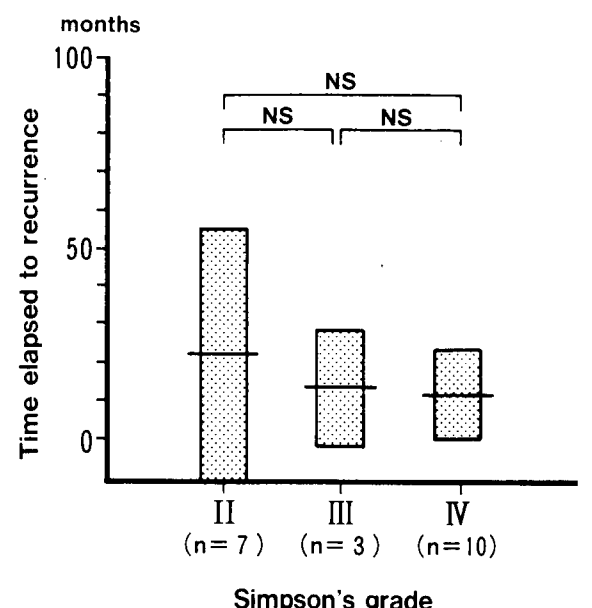

Fig. 2 Simpson's grade and time elapsed to recurrence Time elapsed to recurrence was not affected by Simpson's grade. (NS : statistically not significant)

Table 1 Profile of patients

\begin{tabular}{|c|c|c|c|c|c|c|c|}
\hline $\begin{array}{l}\text { Case } \\
\text { No. }\end{array}$ & Age & Sex & $\begin{array}{l}\text { Primary } \\
\text { site }\end{array}$ & Pathological diagnosis & $\begin{array}{l}\text { Follow-up period } \\
\text { (months) }\end{array}$ & $\begin{array}{c}\text { Recurrence } \\
\text { (times) }\end{array}$ & $\begin{array}{l}\text { Site of } \\
\text { recurrence }\end{array}$ \\
\hline 1 & 18 & $\mathrm{M}$ & parasagittal & papillary & 59 & 2 & marginal \\
\hline 2 & 54 & M & parasagittal & fibroblastic $\Rightarrow$ atypical & 59 & 1 & same \\
\hline 3 & 65 & $\mathrm{~F}$ & falx & atypical & 31 & 2 & same \\
\hline 4 & 65 & F & sphenoidal ridge & fibroblastic $\Rightarrow$ anaplastic & 12 & 2 & same \\
\hline 5 & 37 & M & tentorial & papillary & 89 & 4 & same \\
\hline 6 & 54 & $\mathrm{~F}$ & sphenoidal rigde & atypical & 29 & 3 & marginal \\
\hline 7 & 68 & $\mathrm{M}$ & convexity & atypical & 65 & - & - \\
\hline 8 & 64 & M & parasagittal & anaplastic & 113 & 2 & marginal \\
\hline 9 & 77 & $\mathrm{~F}$ & parasagittal & anaplastic & 44 & - & - \\
\hline 10 & 23 & $\mathrm{M}$ & convexity & atypical & 209 & - & - \\
\hline 11 & 53 & $\mathrm{~F}$ & $\mathrm{C}-\mathrm{P}$ angle & meningotheliomatous $\Rightarrow$ atypical & 79 & 8 & same \\
\hline
\end{tabular}

$\mathrm{C}-\mathrm{P}$ angle : cerebellopontine angle CDDP : cisplatin ADR : deoxorubicin hydrochloride 
ち症例 7, 10 はいずれも atypical meningioma で円蓋 部に原発し, Simpson's grade I ${ }^{15)}$ の手術が施行され, 10 年以上再発なしに経過している。症例 9 は高齢者の傍 矢状部 anaplastic meningioma で, 初回 Simpson's grade II の手術後放射線治療が施行されたが，比較的短 期間で遅発性放射線障害のため performance status の 著しい低下をきたし死亡している（Table 1)。

初回腫瘍摘出術後, 画像診断上腫瘍再增大が認められ, それによる症状が発現しているか，あるいは臨床症状の 発現がない場合でも，画像診断上腫瘍の再增大を認めて 主治医が再手術を施行した時点を再発と定義すると，11 例中 8 例に $1 \sim 8$ 回の再発が認められた。再発率は $73 \%$, 再発に先立つ 22 回の手術から再発までの期間中央
值は 15 力月であった。腫瘍の再発部位は，5例では原発 巣と同一部位での再増大であるが，原発巣周辺部を再発 中心とするいわゆる marginal recurrence が 3 例に認め られた。そのうち2例には多発性肺転移を認めた(Table 1).

\section{3 手術的腫瘍摘出度}

11 例の全経過を通じて 34 回の腫埴摘出術が施行され ており, 内訳は Simpson's grade I 3 回, Simpson's grade II 11 回, Simpson's grade III 4 回, Simpson's grade IV 16 回であった. Simpson's grade I の術後再 発を認めた例はなく, Simpson's grade I に対して Simpson's grade II〜IVの術後の再発の有無を $\chi^{2}$ 検定

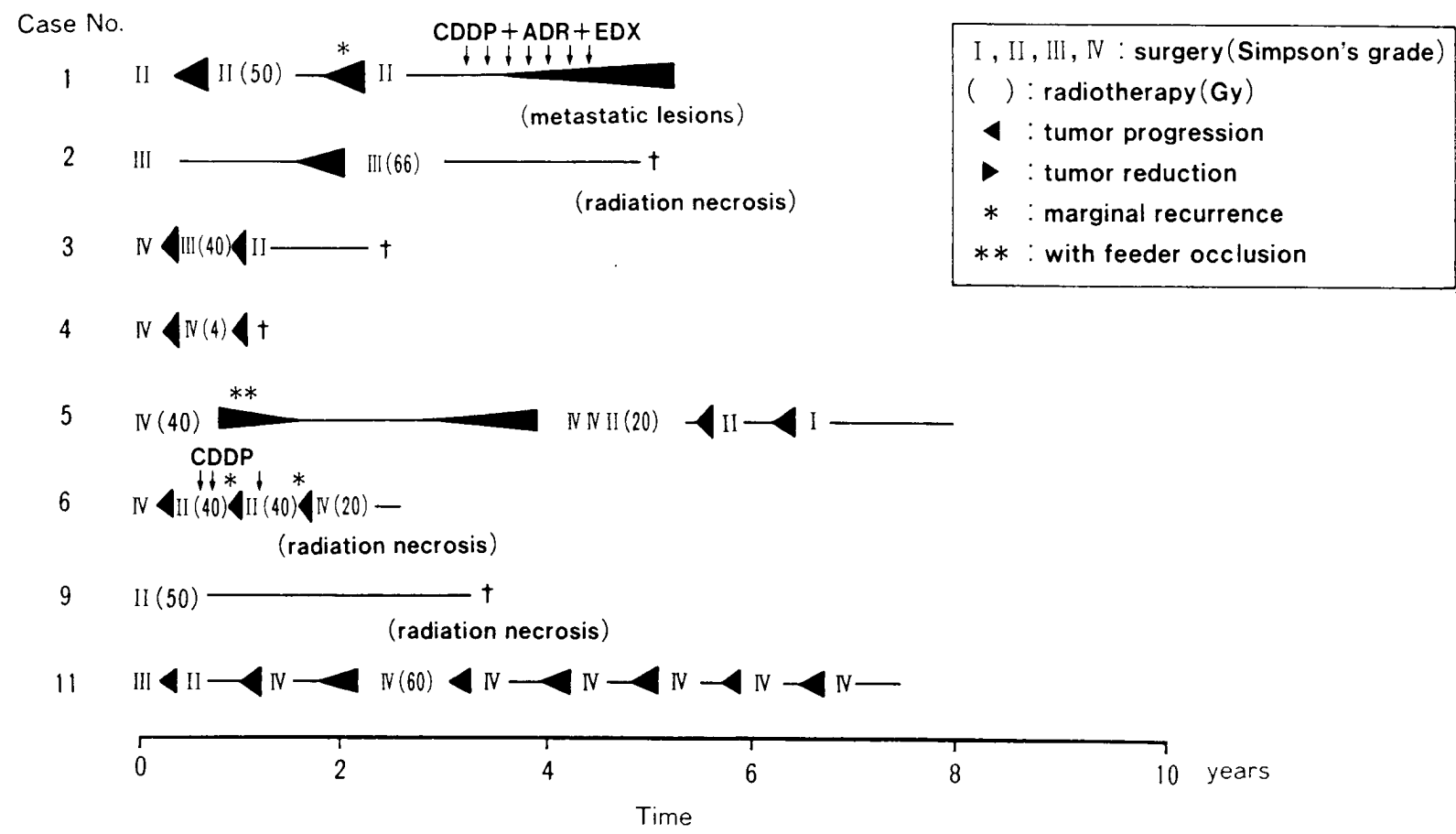

Fig. 3 Therapies and clinical course

of malignant meningioma

\begin{tabular}{|c|c|c|c|c|}
\hline $\begin{array}{c}\text { Operation } \\
\text { (times) }\end{array}$ & $\begin{array}{c}\text { Radiation } \\
\text { therapy }\end{array}$ & Chemotherapy & Metastasis & Outcome \\
\hline 3 & $50 \mathrm{~Gy}$ & $\mathrm{CDDP}+\mathrm{ADR}+\mathrm{EDX}$ & lung & alive \\
\hline 2 & $66 \mathrm{~Gy}$ & - & - & dead (radiation necrosis) \\
\hline 3 & $40 \mathrm{~Gy}$ & - & - & dead (pneumonia) \\
\hline 2 & $4 \mathrm{~Gy}$ & - & - & dead (cerebral herniation) \\
\hline 6 & $40+26 \mathrm{~Gy}$ & - & - & alive \\
\hline 4 & $40+20+40 \mathrm{~Gy}$ & CDDP & lung & alive \\
\hline 1 & - & - & - & alive \\
\hline 2 & - & - & - & dead (pneumonia) \\
\hline 1 & $50 \mathrm{~Gy}$ & - & - & dead (radiation necrosis) \\
\hline 1 & - & - & - & alive \\
\hline 9 & $60 \mathrm{~Gy}$ & - & - & alive \\
\hline
\end{tabular}

EDX : cyclophosphamide 
すると，危険率 0.01 以下で統計学的有意差を認めた. Simpson's grade II, III, IV の術後で再発が認められた 時，その再発までの期間を比較すると Simpson's grade II, III, IV の 3 群間に有意差は認めなかった (Fig. 2)。

\section{4 放射線治療}

照射線量 4 100 Gy の放射線治療が 11 例中 8 例に施 行された (Table 1)。一定の基準は設けられていないが， 最近の症例では再発時の術後にリニアックを用いて対向 2 門のX線，6メガボルト，通常分割照射とした $40 \mathrm{~Gy}$ の局所照射が好んで行われている．放射線治療後に再発 が認められなかった例は，早期に遅発性放射線障害によ り死亡した症例 9 のみであり，放射線治療の悪性髄膜腫 再発予防効果は認めがたい。

症例 5 が放射線治療後に約 50\%の腫瘍縮小を呈した が, この症例では同時に腫瘍の栄養血管の結禁術が施行 されており，その他の症例ではいずれも腫瘍縮小効果は

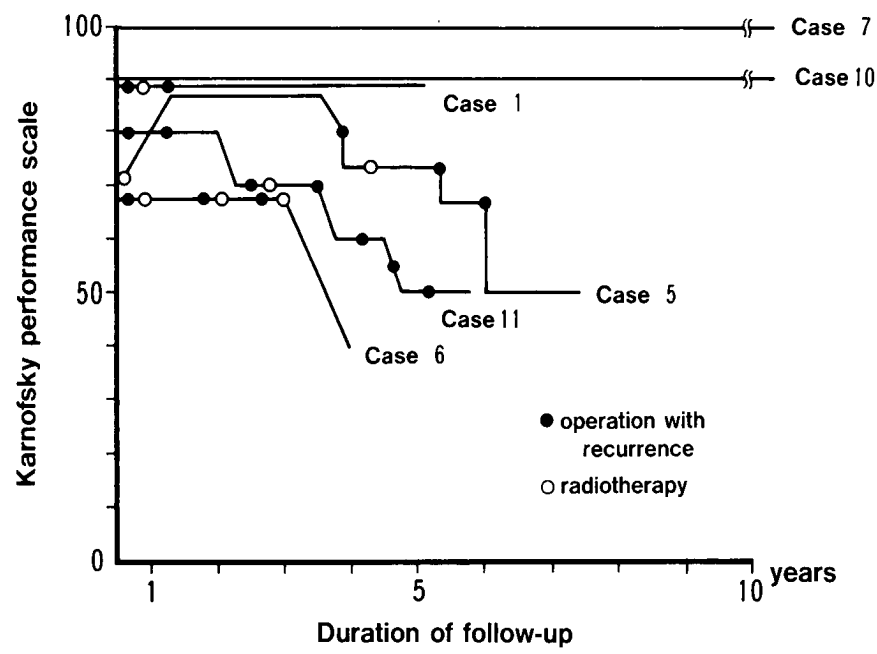

A : Good outcome group

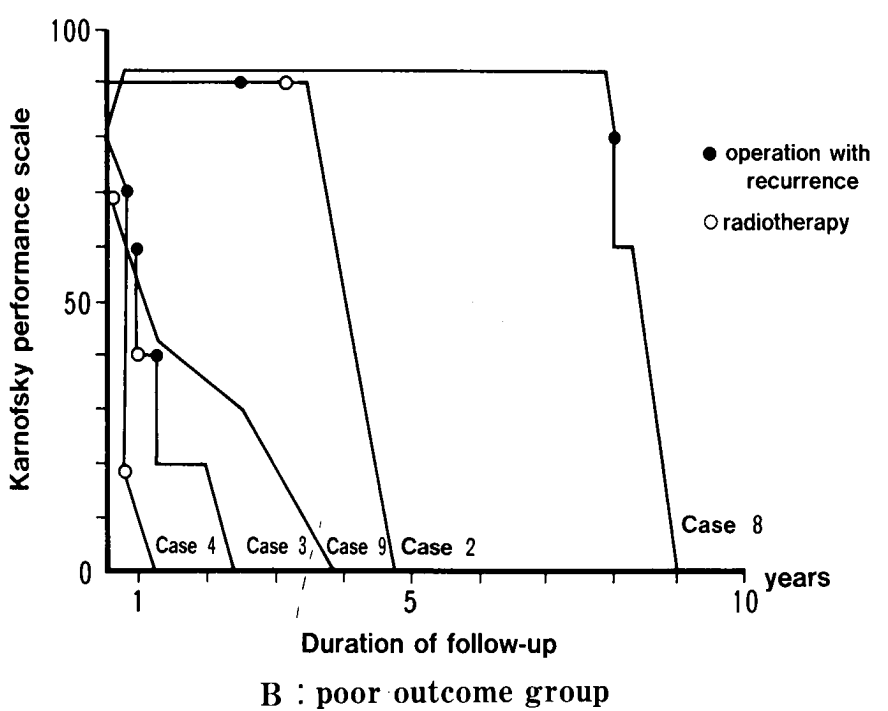

Fig. 4 Changes of performance status
認めなかった。症例 5 を含めて, 放射線治療後の再発ま での期間が他の再発までの期間に比べ少しでも延長した 例は，症例 1 およ゙ 2 と再発様式が marginal recurrence であった症例 6 の合計 4 例であった。一方，遅発 性放射線障害が 3 例と高率に発現したが，うち 2 例は高 線量の照射が，1例は高齢であることがその誘因であっ たと思われた。遅発性放射線障害が直接死亡の原因に なったと考えられたのは2 例であった (Fig. 3).

化学療法は 2 例に施行され, 症例 1 では特に肺転移巣 を狙って全身投与を, 症例 6 には選択的に外頸動脈内投 与したが，いずれも腫瘍の増大に影響は与えなかった。

\section{Performance status}

初診から 6 力月以降の Karnofsky performance scale の変化を, 転帰良好群と転帰不良群に分けて検討した。 転帰良好群は 6 例で, その中には頻回の再発と手術にも かかわらず，画像診断上の腫瘍增大のみの時期に再手術 を施行して performance status の低下を招来せずに経 過した例が 4 例みられた (Fig. 4A)。一方, 転㷌不良群は 5 例で, 発症時の年齢が高いものが多かった (Fig. 4B). Performance status 低下の原因は, 腫瘍摘出術, 遅発性 放射線障害, 見過ごされた再発であった。発症年齢 60 歳 以上および末満と生存曲線の間には統計学的有意差を認 めた（generalized Wilcoxon 検定， $\mathrm{p}<0.05$ ) (Fig. 5).

\section{考 察}

まず, 対象として atypical, anaplastic, papillary meningioma を選択した理由は，最近の報告では再発を 含めた臨床的特性から，それらが 1 グループとして報告

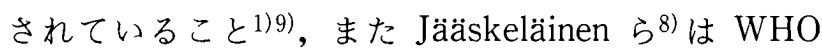
grade I (benign) と grade II (atypical), III (anaplas-

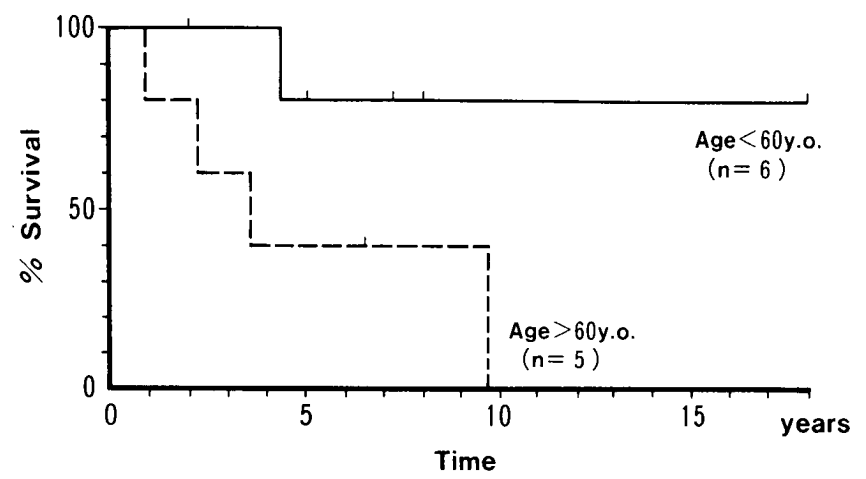

Fig. 5 Age and survival curves

Survival curves illustrated by Kaplan-Meier's method. There is significant difference at $\mathrm{p}<0.05$ by generalized Wilcoxon test. 
tic, papillary）との間に腫崵倍加時間で差があると報告 していることから，これらを一括して対象とするのが合 理的と考えたからである. 対象となった 11 例の平均年 齢, 男女比 (男性優位), 悪性髄膜腫の全髄膜腫に対する 頻度は従前の報告と変わらない10111)13)14)。

\section{1 手術的摘出度亡再発・予後について}

いわゆる良性髄膜腫に比べ悪性髄膜腫の再発率は格段

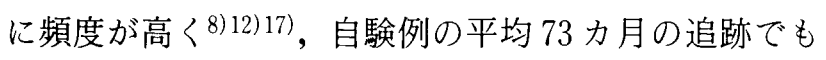
$73 \%$ の症例に再発がみられた。手術的摘出度と再発の関 係をみると, atypical meningioma で Simpson's grade I の手術が施行されて, 10 年以上再発を認めない 2 例 が特に目立つ。再発しなかった要因がその組織診断と手 術的摘出度 (Simpson's grade) のどちらにあるのか一 概には論じられないが, 他の atypical meningioma の臨 床経過をみるかぎり，手術的摘出度により依存した事象 であるとの考えをもっている.この 2 例以外は臨床的に 悪性疾患の経過を辿った。われわれの症例の検討での手 術的摘出度に対する結論は, Simpson's grade I の手術 が施行できれば再発は少ないが, Simpson's grade II 〜IVの手術ではいずれの例も再発をきたし，その手術か ら再発までの期間に差はなかったというものであった。

一般に髄膜腫の手術摘出度と予後の関係の報告は, Kallio ら ${ }^{10)}$ の 935 例の検討が症例数が多く, Simpson's grade II と III の間に差があったと報告している。一方 悪性髄膜腫では，小島ら ${ }^{11)}$ は 25 例の悪性例を含む 110 例の髄膜腫の検討で, Simpson's grade II では有意に悪 性例での再発が多かったと述べている，われわれの検討 からも悪性髄膜腫では，良性例に対してその生物学的態 度の違(3)812) から Simpson's grade I と II の間に差 が生じるものであると思われる。他に報告は見当たらな いが, 不完全摘出例の再発までの期間と手術的摘出度と の間に差が生じないのも, 腫瘍のより早い成長に起因す ると考えられる。

\section{2 放射線治療亡再発・予後について}

8 例の放射線治療に対する効果では, 1 例で照射後に 腫崵の縮小を認めたが，この例ではそれに先立つ手術時 に (Simpson's grade IV) 主栄養血管である marginal tentorial artery の結禁術が施行されていた。䯣膜腫に対 する栄養動脈の塞栓術後, 数力月の経過で腫煌の縮小が みられることが知られており ${ }^{16)}$, 他に悪性髄膜腫に対す る放射線治療の腫瘍縮小効果の報告も少なく, 自験例で も腫瘍縮小効果が他の症例で得られていないことから， 腫湟の縮小は放射線治療の効果とは考えなかった。その
他の再発までの期間延長を認めた例でも，期間の差は症 例の全経過からみればわずかであり，8例のうち遅発性 放射線障害で死亡した 1 例以外は全例再発を認めてい る.現状では臨床的に放射線治療の有効性を認めるには 至らなかった。

歷史的浧性髄膜腫に対する放射線治療の根拠となつ たのは, 1975 年の Wara ら ${ }^{18)}$ の悪性髄膜腫 3 例を含む髄 膜腫 213 例の検討で, 放射線治療は不完全切除後の腫瘍

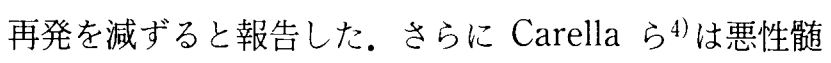
膜腫 11 例に放射線治療を行い，1〜10 年の追跡で 8 例 が生存して扔り，悪性髄膜腫には放射線治療の適応があ ると述べ, 小島ら ${ }^{11)}$ は 25 例の覀性髄膜腫の検討で, 20 例 に放射線治療を施行し, 放射線治療群に再発が少なかっ たと述べた。しかし，自験例の生存期間中央值は 9 年 7 カ月にあり, Carella ら ${ }^{4)}$ の根拠をもつてしても放射線治 療が有効であるとはいえず，また小島らの症例には放射 線治療の効果が散見される(6) hemangiopericytoma が 6 例含まれて抢り，われわれの検討とは同列に扱えない。 一方, Jääskeläinen $ら^{9)} 20$ 例の anaplastic meningioma のうち完全摘出後 5 例に放射線治療を行ったが, いずれも再発し，放射線治療が有効である根拠はなにも 見出されず，さらに頻回な再手術が予想される悪性髄膜 腫症例に頭皮損傷を与えるべきでないと否定的見解を述 べている，われわれも自験例の解析結果から, 悪性髄膜 腫の治療に放射線治療を多用することは戒めなければな らないと考えている。

しかし，今後どうしても手術的摘出に限界がみえた時 と, 補助療法として予想されるものをあげるとすれば, 血管内手術手技を用いた治療と並んで, 少なくとも副作 用が隇じられると思える stereotaxic radiosurgeryとし ての放射線治療は残された道であると思われる。

\section{Performance status について}

Performance status の観点から自験例の経過をみる と, performance status を保ちつつ腫崵の制御ができた 例では予後がよく, 頻回に再発しても performance status が保たれていた例は，いずれも短期間の画像診断 フォローアップにより症状発現前に腫瘍の再増大を診断 し，再手術を施行しえた例である. Performance status 低下の原因が, 腫湯摘出術, 遅発性放射線障害, 見過ご された再発であったことを併せて考えると，手術的腫瘍 摘出度が Simpson's grade II〜IV の間では再発までの 期間に差がないので，もし Simpson's grade I が望め ないのであれば performance status を考虑して, 代表 的頭蓋内悪性腫瘍の神経膠芽腫での gross total resec- 
tion の効用2) と同様に解釈し，侵襲の少ない術式を選択 すべきである。

したがって, 腫瘍再増大の早期診断と, 頻回でも小さ いうちに腫瘍の摘出術を重ね，腫瘍をコントロールして いくことが悪性髄膜腫の治療上肝要な点と思われる。

\section{結 語}

自験例の検討から悪性髄膜腫の治療方針を述べると，

(1) 可能なら Simpson's grade I の手術を行う。それ 以外はなるべく performance status を保存できる方法 を術式として選択する。

(2) 術後は画像診断のフォローアップを密に行い, 症状 発現前に腫瘍の再増大を発見できるよう努める。

(3) 腫瘍のコントロールは，もっぱら腫瘍摘出手術に よって行い，ここでも performance status 保存に努め る.

(4)放射線治療は効果が期待しがたく，手術的に腫瘍の 制御が困難となった時にのみ，やむをえず施行する。 以上のごとくまとめられる。

本論文の要旨は第 51 回日本脳神経外科学会総会 (1992 年, 鹿児 島）において発表した。

\section{文 献}

1) Alvarez F, Roda JR, Romero MP, Morales C, Sarmiento MA, Blázquez MG: Malignant and atypical meningiomas : A reappraisal of clinical, histological, and computed tomographic features. Neurosurgery $20: 688-694,1987$.

2) Ammirati M, Vick N, Liao Y, Chiric I, Mikhael M : Effect of extent of surgical resection on survival and quality of life in patients with supratentorial glioblas. tomas and anaplastic astrocytomas. Neurosurgery 21:201-206, 1987.

3) Cho KG, Hoshino $T$, Nagashima $T$, Murovic JA, Wilson $\mathrm{CB}$ : Prediction of tumor doubling time in recurrent meningiomas. J Neurosurg 65:790-794, 1986.
4) Carella RJ, Ransohoff J, Newall J : Role of radiation therapy in the management of meningioma. Neurosurgery 10:332-339, 1982.

5) Fields WS : Primary brain tumors. A review of his. tologic classification. New York, Springer, 1989.

6) Fukui M, Kitamura K, Ohgami S, Takaki T, Kinoshita K, Watanabe K, Mihara K : Radiosensitivity of meningioma. Acta Neurochir $36:$ 47-60, 1977.

7) Fukui M, Shima F, Abe M, Tsukamoto Y, Hayabuchi $\mathrm{N}$, Numaguchi $\mathrm{Y}$, Kitamura $\mathrm{K}$ : Recurrent intracranial meningioma with metastasis in the skull. Neurol Med Chir (Tokyo) $20: 107-111,1980$.

8) Jääskeläinen J, Haltia M, Laasonen E, Wahlström T, Valtonen $\mathrm{S}$ : The growth rate of intracranial meningiomas and its relation to histology. Surg Neurol $24: 165-172,1985$.

9) Jääskeläinen J, Haltia M, Servo A : Atypical and anaplastic meningiomas: radiology, surgery, radiotherapy, and outcome. Surg Neurol 25:233-242, 1986.

10) Kallio M, Sankila R, Hakulinen T, Jääskeläinen J : Factors affecting operative and excess long-term mortality in 935 patients with intracranial meningioma. Neurosurgery. $31: 2-12,1992$.

11）小島 精, 和賀志郎, 伊藤浩二, 松原年生, 久我純弘： 悪性髄膜腫の検討. 脳外 18：939-946，1990。

12) Lee KS, Hoshino T, Rodriguez LA, Bederson J, Davis RL, Wilson CB : Bromodeoxyuridine labeling study of intracranial meningiomas : proliferative potential and recurrence. Acta Neuropathol $80: 311-317,1990$.

13) Salcman M: Malignant meningiomas. in Al-Mefty (ed) : Meningiomas. New York, Raven Press, 1991, pp. $75-85$.

14) Rohringer M, Sutherland GR, Louw DF, Sima AAF : Incidence and clinicopathological features of menin gioma. J Neurosurg 71:665-672, 1989.

15) Simpson D: The recurrence of intracranial meningiomas after surgical treatment. $J$ Neurol Neurosurg Psychiatry 20:22-39, 1957.

16）高橋 明：新しい液体塞栓療法の開発一エストロゲンア ルコールとポリビニルアセテート併用療法について．北 海道脳神経疾患研究所医誌 4:11-24，1991.

17）和賀志郎, 山下純宏, 半田 肇：髄膜腫の再発. Neurol Med Chir (Tokyo) $17: 203-208,1977$.

18) Wara WM, Sheline GE, Newman H, Townsend JJ, Boldrey EB : Radiation therapy of meningiomas. AJR 123 : 453-458, 1975. 
悪性邻有膜腫の䧗床的検討と治療方針

一手術的摘出度，再発，放射線治療， performance status に関する検討から一

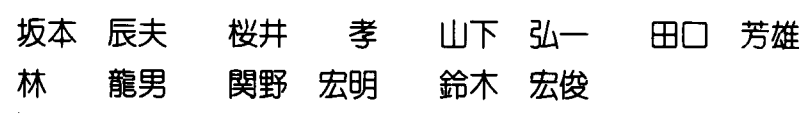

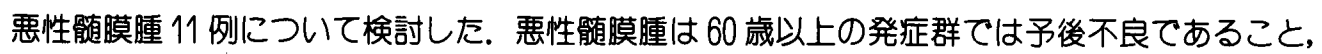
Simpson's grade । の術後再発例はなかつたが, Simpson's grade $\| \sim N$ までの間では再 発までの期間に差がなかつたこと，現状ては放射線治療の効果は否定的であること，再発を綠り返し ても performance status の低下を避けられれば予後良好であることなどが判明した。

以上より悪性葡膜腫の治療方針は, できれば Simpson's grade | の手術を行うこと, 画像診 断のフォローアップを密に行い, 症状発現前に畽瘍の再増大を発見し, 無理のない cyto-reduction surgery を重ねることであると考えられた.

脳外哂 $2: 295-301,1993$

\section{脳神経外科要ャーナル}

巻頭言

九州大学 福 井 仁士

原 著

小児モヤモヤ病に対する大網移植術の新しい手技

大阪脳神経外科病院 東保

肇，他

ガンマナイフによる脳動静脈奇形の初期効果について 小牧市民病院 田中 孝幸, 他

破裂脳動脈瘤急性期におけるアミノ酸投与の諸栄養指数への影響 大阪脳神経外科病院 東保

肇，他

AVM 全摘出術の痙攣に及ぼす影響一長期経過観察例における検討一 神戸大学 頃末 和良, 他 軽微な頸椎外傷後の頸髄症患者における動態 MRI の検討 ………………...奈良県立医科大学 森本 哲也, 他 $\mathrm{N}$-isopropyl-p-[ $\left.{ }^{123} \mathrm{I}\right]$ iodoamphetamine ( $\left.{ }^{123} \mathrm{I}-\mathrm{IPM}\right)$ double injection 法

による acetazolamide test への応用とその検討 ·順天堂大学伊豆長岡病院 森 健太郎, 他 頸椎椎間板へルニアに対する anterior discectomy without fusion の長期成績

Diffuse brain injury の予後決定因子の検討

国立大阪南病院 湯浅 隆史, 他

-Prognosis determining scale の作成-

\section{症例報告} 東海大学 柴田 將良, 他

Failed EDAS に対する直接的血行再建術

一著効を示した major stroke 発症の小児モヤモヤ病の 1 例一 大阪脳神経外科病院 東保 肇, 他 術後 vitamin $\mathrm{K}$ 欠乏性頭蓋内出血をきたしたクモ膜下出血の 2 例 ·飯塚病院 稲富雄一郎, 他

Dumbbell 状に発育した高位後綻隔神経節細胞腫に対する二期的手術例 香川労災病院 真壁 哲夫, 他 小脳出血に続発した脳腫崵の 1 例 多中心性神経膠腫と紛らわしい画像を呈した悪性星細胞腫と脳梗塞の 1 合併例 八尾病院 飯田 疗一, 他

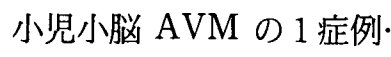
梶川病院 松川 雅則, 他 須崎くろしお病院 桑原 正行, 他 